\title{
Corynebacterium suicordis sp. nov., from pigs
}

\author{
Correspondence \\ J. F. Fernández-Garayzábal \\ garayzab@vet.sim.ucm.es
}

\author{
A. I. Vela, ${ }^{1}$ A. Mateos, ${ }^{1}$ M. D. Collins, ${ }^{2}$ V. Briones, ${ }^{1}$ R. A. Hutson, ${ }^{2}$ \\ L. Domínguez ${ }^{1}$ and J. F. Fernández-Garayzábal ${ }^{1}$ \\ ${ }^{1}$ Departamento de Patología Animal I (Sanidad Animal), Facultad de Veterinaria, Universidad \\ Complutense, 28040 Madrid, Spain \\ ${ }^{2}$ School of Food Biosciences, University of Reading, Reading RG6 6AP, UK
}

\begin{abstract}
Nineteen strains of Gram-positive, non-motile, non-spore-forming, catalase-positive, rod-shaped bacteria isolated from pigs were characterized by using biochemical, molecular chemical and molecular genetic methods. Two distinct groups of organisms were discerned, based on their colonial morphology, CAMP (Christie-Atkins-Munch-Petersen) reaction and numerical profile by using the API Coryne system. The first group (13 strains) gave a doubtful discrimination between Corynebacterium striatum and Corynebacterium amycolatum, whilst the second group (six strains) were identified tentatively as Corynebacterium urealyticum. Comparative 16S rRNA gene sequencing studies demonstrated that all of the isolates belonged phylogenetically to the genus Corynebacterium. The first group of organisms was highly similar to Corynebacterium testudinoris with respect to $16 \mathrm{~S}$ rRNA gene sequences and physiological characteristics, whereas the remaining six isolates formed a hitherto unknown subline within the genus, associated with a small subcluster of species that included Corynebacterium auriscanis and its close relatives. The unknown Corynebacterium sp. was distinguished readily from these and other species of the genus by biochemical tests. Based on both phenotypic and phylogenetic evidence, it is proposed that the new isolates from pigs should be classified as a novel species, Corynebacterium suicordis sp. nov. The type strain is P81/02 $2^{\top}$ (=CECT $5724^{\top}=$ CCUG $46963^{\top}$ ).
\end{abstract}

Corynebacteria are a heterogeneous group of Grampositive, high-G $+\mathrm{C}$ content, rod-shaped bacteria that belong phylogenetically to the Actinobacteria. Corynebacteria are found in a broad range of environments (such as dairy products, soil, sediments and aquatic sources), but particularly in man and other animals. Some corynebacteria are well-established pathogens of man and animals, whereas many others occur as part of the normal flora of skin and mucous membranes. There has recently been a considerable expansion in the number of described corynebacterial species, which is mainly due to growing awareness of these organisms as opportunistic pathogens and the availability of improved molecular taxonomic methods, such as 16S rRNA gene sequencing, which have greatly improved the identification of these organisms (Funke et al., 1997). In the past decade, over 30 novel species have been assigned to the genus, the majority of

Published online ahead of print on 13 June 2003 as DOI 10.1099/ ijs.0.02645-0.

Abbreviation: CAMP, Christie-Atkins-Munch-Petersen.

The GenBank/EMBL/DDBJ accession number for the 16S rRNA gene sequence of Corynebacterium suicordis strain CECT $5724^{\top}$ is AJ504424.

A full version of the phylogenetic tree is available as supplementary material in IJSEM Online. which originated from human clinical specimens and, to a lesser extent, from veterinary sources. There is, however, good evidence that much novel corynebacterial diversity remains to be discovered from human (e.g. Funke et al., 1998; Sjödén et al., 1998; Tanner et al., 1999; Renaud et al., 2001; Shukla et al., 2001) and especially animal (e.g. Fernández-Garayzábal et al., 1997, 1998; Collins et al., 1999, 2001a, b; Goyache et al., 2003) sources. In the course of a study of bacteria isolated from respiratory infections of pigs, we have characterized 19 Corynebacterium-like organisms by using phenotypic and molecular taxonomic methods. Based on the presented findings, we describe a hitherto unknown Corynebacterium species, Corynebacterium suicordis $\mathrm{sp}$. nov.

Sources from which bacterial strains were isolated are given in Table 1. Pigs were between 3 and 15 days old and were kept under intensive management conditions. All strains were isolated on Columbia blood agar plates (bioMérieux) and incubated for $48 \mathrm{~h}$ at $37^{\circ} \mathrm{C}$ under aerobic and anaerobic conditions. Strains were characterized biochemically by using the API Coryne (version 2.0), API $50 \mathrm{CH}$ and API ZYM systems (bioMérieux) according to the manufacturer's instructions. API $50 \mathrm{CH}$ strips were incubated for $48 \mathrm{~h}$ at $37^{\circ} \mathrm{C}$. The CAMP (Christie-Atkins-Munch-Petersen) test with Staphylococcus aureus ATCC 25923 was determined according to standard procedures (Funke et al., 1997). 
Table 1. Origin of the swine strains studied

\begin{tabular}{|c|c|c|}
\hline Strain & Source/lesion & Isolation \\
\hline P500/01, P587/01, P1/02 & Heart/pericarditis & Pure culture \\
\hline $\mathrm{P} 494 / 01, \mathrm{P} 499 / 01$ & Heart/pericarditis & Mixed culture $^{*}$ with Staphylococcus sciuri \\
\hline $\mathrm{P} 125 / 02$ & Heart/pericarditis & Mixed culture $^{*}$ with Streptococcus alactolyticus \\
\hline $\mathrm{P} 81 / 02^{\mathrm{T}}$ & Heart/pericarditis & Mixed culture $\dagger$ with Moraxella osloensis \\
\hline P30/02 & Pleural cavity/pleuritis & Mixed culture $\dagger$ with Streptococcus alactolyticus \\
\hline P644/02 & Pleural cavity/pleuritis & Pure culture \\
\hline $\mathrm{P} 47 / 02$ & Lung/pneumonia & Mixed culture $\dagger$ with Streptococcus uberis \\
\hline P591/01 & Lung/pneumonia & $\begin{array}{l}\text { Mixed culture } \dagger \text { with Haemophilus parasuis and } \\
\text { Pasteurella multocida }\end{array}$ \\
\hline $\mathrm{P} 201 / 02$ & $\begin{array}{l}\text { Mediastinic lymph nodes/ } \\
\text { lymph nodes enlarged }\end{array}$ & Mixed culture $^{\star}$ with Streptococcus sanguinis \\
\hline
\end{tabular}

*Corynebacterium isolates exhibited majority growth with respect to the other bacterium.

$\dagger$ Corynebacterium isolates exhibited minority growth with respect to the other bacterium.

Lipophilic requirements were determined by growing the isolates on brain heart infusion agar supplemented with $1 \%$ Tween 80 , in comparison with brain heart infusion agar that lacked lipid supplementation. Cell-wall murein was prepared by mechanical disruption of cells and complete acid hydrolysates were analysed as described by Schleifer \& Kandler (1972). Fatty acid methyl esters were prepared and analysed as described by Kämpfer \& Kroppenstedt (1996). The presence of mycolic acids was investigated by GLC analysis of trimethylsilylated derivatives (Klatte et al., 1994). Comparative 16S rRNA gene sequence analyses were performed as described previously (Vela et al., 2002). The closest known relatives of the new isolates were determined by performing database searches. A phylogenetic tree was constructed according to the neighbour-joining method with the program NEIGHBOR (Felsenstein, 1989). Stability of the groupings was estimated by bootstrap analysis (500 replications) by using the programs DNABOOT, DNADIST, NEIGHBOR and CONSENSE (Felsenstein, 1989).

The 19 isolates consisted of Gram-positive, non-motile, non-spore-forming, catalase-positive, rod-shaped organisms. They were non-haemolytic and non-lipophilic. Two groups of strains were observed, according to colony morphology and CAMP reaction. Thirteen strains (designated P587/01, P1/02, P5/02, P34/02, P644/02, P719/02, $\mathrm{P} 30 / 02, \mathrm{P} 47 / 02, \mathrm{P} 125 / 02, \mathrm{P} 201 / 02, \mathrm{P} 591 / 01, \mathrm{P} 8 / 02$ and P495/01) grew on Columbia sheep blood agar, forming yellow-pigmented, low-convex colonies, and were CAMP test-positive after $72 \mathrm{~h}$. These strains were biochemically homogeneous, producing acid from glucose, ribose, maltose and sucrose, but not from D-xylose, mannitol, lactose or glycogen. They hydrolysed aesculin, but not gelatin or urea, and they reduced nitrate. The strains gave a numerical profile with the API Coryne kit of 3040325, which corresponds to a doubtful discrimination between Corynebacterium striatum and Corynebacterium amycolatum. However, these latter species produce alkaline phosphatase and do not hydrolyse aesculin (Martínez-Martínez et al., 1995; Funke et al., 1996), whereas the swine isolates are alkaline phosphatase-negative and do hydrolyse aesculin. In addition, the swine isolates can be differentiated from C. striatum by the inability of the latter species to produce acid from maltose or ribose (Martínez-Martínez et al., 1995). The 13 swine isolates gave positive reactions for ester lipase C8, esterase C4, cystine arylamidase, naphtholAS-BI-phosphohydrolase, pyrazinamidase and $\alpha$-glucosidase, but no activity was detected for leucine arylamidase, lipase C14, alkaline phosphatase, acid phosphatase, pyrrolidonyl arylamidase, $\beta$-glucosidase, $\beta$-glucuronidase, $\alpha$-mannosidase, $\alpha$-galactosidase, $\beta$-galactosidase, $\alpha$-fucosidase, chymotrypsin, trypsin or valine arylamidase. To further investigate the identity of this group of organisms, comparative $16 \mathrm{~S}$ rRNA gene sequencing was performed. Almost-complete $16 \mathrm{~S}$ rRNA gene sequences (>1400 nt) of two representative strains of the group (P30/02 and P591/01) and approximately $1000 \mathrm{nt}$ of the $16 \mathrm{~S}$ rRNA gene sequence of the other 11 strains were determined and found to display $99 \cdot 8-100 \%$ sequence similarity to each other. Sequence searches of GenBank/EMBL revealed that the 13 isolates displayed $99 \cdot 8-99 \cdot 9 \% 16 \mathrm{~S}$ rRNA gene sequence similarity 
to the type strain of Corynebacterium testudinoris. This result was found to be consistent with the overall biochemical and physiological characteristics of this species (Collins et al., 2001b). However, by using the API Coryne and API ZYM systems, C. testudinoris does not produce pyrazinamidase or cystine arylamidase, but does produce acid phosphatase (Collins et al., 2001b), whereas the swine strains gave opposite reactions for these tests.

The six remaining strains recovered from pigs (designated $\mathrm{P} 494 / 01, \mathrm{P} 496 / 01, \mathrm{P} 499 / 01, \mathrm{P} 500 / 01, \mathrm{P} 502 / 01$ and $\mathrm{P} 81 / 02^{\mathrm{T}}$ ) grew on Columbia sheep blood agar, forming small (diameter after $48 \mathrm{~h}$ incubation, <1-2 $\mathrm{mm}$ ), whitish, circular, smooth colonies and were CAMP test-negative. These strains hydrolysed urea, but not aesculin or gelatin. They did not reduce nitrate and gave positive reactions for pyrazinamidase and alkaline phosphatase. No activity was detected for pyrrolidonyl arylamidase, $\beta$-glucuronidase, $\beta$-galactosidase or $\alpha$-glucosidase. None of the strains produced acid from glucose, maltose, ribose, lactose, sucrose, glycogen or mannitol. They produced API Coryne profile 2101004, corresponding to a good identification of Corynebacterium urealyticum. However, this species does not grow anaerobically (Funke et al., 1997), whereas the six swine isolates were able to grow under anaerobic conditions. The six unknown isolates were subjected to further biochemical characterization by using the API $50 \mathrm{CH}$ and API ZYM systems. None of the strains produced acid from glycerol, erythritol, D-arabinose, L-arabinose, D-xylose, L-xylose, inositol, adonitol, methyl $\beta$-xyloside, galactose, D-fructose, D-mannose, L-sorbose, rhamnose, methyl $\alpha$-D-mannoside, methyl $\alpha$-D-glucoside, sorbitol, $N$-acetyl- $\beta$-glucosamine, amygdalin, arbutin, salicin, cellobiose, melibiose, trehalose, inulin, melezitose, D-raffinose, xylitol, $\beta$-gentibiose, D-turanose, D-lyxose, D-tagatose, D-fucose, L-fucose, D-arabitol, L-arabitol, 5-ketogluconate or 2-ketogluconate. The six strains gave positive reactions for esterase $\mathrm{C} 4$, ester lipase C8, acid phosphatase and naphthol-AS-BI-phosphohydrolase, but no activity was detected for lipase C14, leucine arylamidase, valine arylamidase, cystine arylamidase, trypsin, chymotrypsin, $\alpha$-galactosidase, $\beta$-glucosidase, $\alpha$-mannosidase or $\alpha$-fucosidase. To further clarify the taxonomic position of this second group of strains, their $16 S$ rRNA gene sequences were investigated. All six strains were highly genetically related to each other, exhibiting $99 \cdot 8-100 \%$ sequence similarity (based on a comparison of 1000 bases). The almost-complete 16S rRNA gene sequence $(>1400 \mathrm{nt})$ of a representative strain $\left(\mathrm{P} 81 / 02^{\mathrm{T}}\right)$ was determined and searches of GenBank/EMBL revealed that its nearest relatives were Corynebacterium species. A tree constructed by using the neighbour-joining method, depicting the phylogenetic position of the second group of swine isolates within the genus Corynebacterium, is shown in Fig. 1. The unknown bacterium (as exemplified by strain $\mathrm{P} 81 / 02^{\mathrm{T}}=$ CECT $5724^{\mathrm{T}}$ ) formed a distinct subline within the genus Corynebacterium, which was associated with a small subcluster of species that included Corynebacterium auriscanis, Corynebacterium falsenii, Corynebacterium

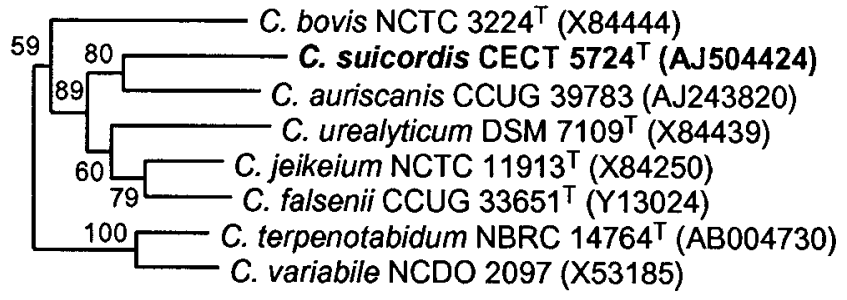

$1 \%$

Fig. 1. Unrooted tree based on $16 \mathrm{~S}$ rRNA, showing the phylogenetic relationships of Corynebacterium suicordis sp. nov. Bootstrap values (expressed as a percentage of 500 replications) are given at branching points. Bar, $1 \%$ sequence divergence.

jeikeium and C. urealyticum. Pairwise sequence comparisons revealed similarities of $95 \cdot 8,95 \cdot 2,95 \cdot 2$ and $94 \cdot 3 \%$, respectively, with the aforementioned species. Other corynebacterial species displayed substantially lower levels of similarity (data not shown). 16S rRNA gene sequence divergence values of $3 \%$ or more are now generally recognized to demonstrate that organisms are unrelated at the species level (Stackebrandt \& Goebel, 1994). Biochemical distinctiveness of the unidentified pig bacterium, in concert with the observed $4 \%$ or greater sequence divergence from all currently defined Corynebacterium species, clearly indicates that the bacterium merits novel species status. We therefore propose that the six strains from pigs should be classified as Corynebacterium suicordis sp. nov. Tests that are useful for differentiation of C. suicordis from its nearest phylogenetic relatives are shown in Table 2. Several species of Corynebacterium have been associated with heart infections in humans (Malik \& Johari, 1995; Ojeda-Vargas et al., 2000; Knox \& Holmes, 2002). However, no conclusion concerning the clinical significance of C. suicordis as an aetiological agent of pericarditis in pigs can be drawn from the present study, as only one of the isolates was recovered in pure culture. The formal description of C. suicordis and the availability of tests to facilitate its identification will aid the recognition of this species by clinical laboratories in the future and improve knowledge of its distribution and possible association with disease.

\section{Description of Corynebacterium suicordis sp. nov.}

Corynebacterium suicordis (su.i.cor'dis. L. n. sus pig; L. n. cor, cordis heart; N.L. gen. n. suicordis of/from pig heart).

Cells are Gram-positive, non-motile, non-spore-forming rods. Colonies are whitish, circular, smooth, entire and $1-2 \mathrm{~mm}$ in diameter after $48 \mathrm{~h}$ incubation at $37^{\circ} \mathrm{C}$ on sheep blood agar. Facultatively anaerobic, catalase-positive and oxidase-negative. Non-haemolytic, CAMP-negative and non-lipophilic. Nitrate is not reduced. Acid is not produced from D-glucose, maltose, lactose, ribose, sucrose, glycogen, mannitol, glycerol, erythritol, D-arabinose, L-arabinose, D-xylose, L-xylose, adonitol, inositol, methyl 
Table 2. Characteristics that differentiate C. suicordis sp. nov. from its nearest phylogenetic relatives

Taxa are identified as: 1, C. suicordis; 2, C. auriscanis; 3, C. jeikeium; 4, C. falsenii; 5, C. urealyticum; 6, Corynebacterium bovis; 7, Corynebacterium variabile; 8, Corynebacterium terpenotabidum. Data for C. jeikeium, C. urealyticum and C. bovis were obtained from the API Coryne system database and Fernández-Garayzábal et al. (1997); data for C. auriscanis, C. falsenii, C. variabile and C. terpenotabidum were obtained from Collins et al. (1999), Sjödén et al. (1998), Brennan et al. (2001) and Takeuchi et al. (1999), respectively. +, Positive reaction; -, negative reaction; $\mathrm{W}$, weakly positive reaction; $\mathrm{V}$, variable reaction; $(+),(\mathrm{V})$ delayed reaction; ND, not determined.

\begin{tabular}{|lcccccccc|}
\hline Characteristic & $\mathbf{1}$ & $\mathbf{2}^{\star}$ & $\mathbf{3}$ & $\mathbf{4}$ & $\mathbf{5}$ & $\mathbf{6}$ & $\mathbf{7}$ & $\mathbf{8} \dagger$ \\
\hline Anaerobic growth & + & + & - & $\mathrm{W}$ & - & - & - & - \\
Lipophilic & - & - & + & - & + & + & - & - \\
Nitrate reduction & - & - & - & - & - & - & + & - \\
Acid production from: & & & & & & & & \\
$\quad$ Glucose & - & + & + & $(+)$ & - & $\mathrm{V}$ & - & - \\
$\quad$ Maltose & - & - & $-\ddagger$ & $(\mathrm{V})$ & - & - & - & - \\
Ribose & - & - & + & + & - & - & $\mathrm{ND}$ & $\mathrm{ND}$ \\
Trehalose & - & $\mathrm{ND}$ & $\mathrm{ND}$ & + & - & $\mathrm{V}$ & $\mathrm{ND}$ & $\mathrm{ND}$ \\
Production of: & & & & & & & & \\
$\quad$ Alkaline phosphatase & + & + & + & + & $\mathrm{V}$ & + & - & $\mathrm{ND}$ \\
$\quad$ Pyrazinamidase & + & - & + & $\mathrm{W}$ & + & $\mathrm{V}$ & + & $\mathrm{ND}$ \\
$\quad$ Pyrrolidonyl arylamidase & - & + & - & - & - & $\mathrm{V}$ & $\mathrm{ND}$ & $\mathrm{ND}$ \\
$\quad$ Urease & + & - & - & $(+)$ & + & $\mathrm{V}$ & + & + \\
$\quad$ Lipase C14 & - & $\mathrm{V}$ & + & $\mathrm{V}$ & + & $\mathrm{ND}$ & $\mathrm{ND}$ & $\mathrm{ND}$ \\
$\quad$ Leucine arylamidase & - & + & + & $\mathrm{V}$ & + & $\mathrm{ND}$ & $\mathrm{ND}$ & $\mathrm{ND}$ \\
$\quad \beta$-Galactosidase & - & - & - & - & - & + & $\mathrm{ND}$ & $\mathrm{ND}$ \\
& & & & & & & & \\
\hline
\end{tabular}

${ }^{\star}$ C. auriscanis also differs from C. suicordis by its variable aesculin hydrolysis reaction.

$\dagger$ C. terpenotabidum also differs from C. suicordis by its ability to produce acid from mannose.

$\ddagger$ Variable according to Funke et al. (1997).

\$Negative according to Funke et al. (1997).

$\beta$-xyloside, galactose, $\mathrm{D}$-fructose, D-mannose, L-sorbose, rhamnose, methyl $\alpha$-D-mannoside, methyl $\alpha$-D-glucoside, sorbitol, $N$-acetyl- $\beta$-glucosamine, amygdalin, arbutin, salicin, cellobiose, melibiose, trehalose, inulin, melezitose, D-raffinose, xylitol, $\beta$-gentibiose, D-turanose, D-lyxose, D-tagatose, D-fucose, L-fucose, D-arabitol, L-arabitol, 5-ketogluconate or 2-ketogluconate. Urea is hydrolysed, but aesculin and gelatin are not. Activities for pyrazinamidase, esterase C4, ester lipase C8, alkaline phosphatase, acid phosphatase and naphthol-AS-BI-phosphohydrolase are detected. No activity is detected for pyrrolidonyl arylamidase, $\beta$-glucuronidase, $\beta$-galactosidase, $\alpha$-glucosidase, lipase C14, leucine arylamidase, valine arylamidase, cystine arylamidase, trypsin, chymotrypsin, $\alpha$-galactosidase, $\beta$-glucosidase, $\alpha$-mannosidase or $\alpha$-fucosidase. Cell-wall murein is based on meso-diaminopimelic acid. Corynomycolic acids are present $\left(\mathrm{C}_{28}-\mathrm{C}_{36}\right)$. Long-chain cellular acids are of the straight-chain saturated and monounsaturated types, with $\mathrm{C}_{16: 0}, \mathrm{C}_{18: 0}$ and $\mathrm{C}_{18: 1} \omega 9 c$ predominating.

The type strain is $\mathrm{P} 81 / 02^{\mathrm{T}}$ (=CECT $5724^{\mathrm{T}}=\mathrm{CCUG}$ $\left.46963^{\mathrm{T}}\right)$. Isolated from the heart of pigs.

\section{Acknowledgements}

The authors thank A. Casamayor for her technical assistance. This work has been supported by Proinserga s.a. We are grateful to Professor Hans Trüper for help in coining the specific epithet.

\section{References}

Brennan, N. M., Brown, R., Goodfellow, M., Ward, A. C., Beresford, T. P., Simpson, P. J., Fox, P. F. \& Cogan, T. M. (2001). Corynebacterium mooreparkense sp. nov. and Corynebacterium casei sp. nov., isolated from the surface of a smear-ripened cheese. Int J Syst Evol Microbiol 51, 843-852.

Collins, M. D., Hoyles, L., Lawson, P. A., Falsen, E., Robson, R. L. \& Foster, G. (1999). Phenotypic and phylogenetic characterization of a new Corynebacterium species from dogs: description of Corynebacterium auriscanis sp. nov. J Clin Microbiol 37, 3443-3447.

Collins, M. D., Hoyles, L., Foster, G., Sjödén, B. \& Falsen, E. (2001a). Corynebacterium capitovis sp. nov., from a sheep. Int J Syst Evol Microbiol 51, 857-860.

Collins, M. D., Hoyles, L., Hutson, R. A., Foster, G. \& Falsen, E. (2001b). Corynebacterium testudinoris sp. nov., from a tortoise, and Corynebacterium felinum sp. nov., from a Scottish wild cat. Int J Syst Evol Microbiol 51, 1349-1352.

Felsenstein, J. (1989). PHYLIP - Phylogeny inference package (version 3.2). Cladistics 5, 164-166.

Fernández-Garayzábal, J. F., Collins, M. D., Hutson, R. A., Fernández, E., Monasterio, R., Marco, J. \& Domínguez, L. (1997). Corynebacterium mastitidis sp. nov., isolated from milk of sheep with subclinical mastitis. Int J Syst Bacteriol 47, 1082-1085.

Fernández-Garayzábal, J. F., Collins, M. D., Hutson, R. A., Gonzalez, I., Fernández, E. \& Dominguez, L. (1998). Corynebacterium camporealensis sp. nov., associated with subclinical mastitis in sheep. Int J Syst Bacteriol 48, 463-468.

Funke, G., Lawson, P. A., Bernard, K. A. \& Collins, M. D. (1996). Most Corynebacterium xerosis strains identified in the routine clinical laboratory correspond to Corynebacterium amycolatum. J Clin Microbiol 34, 1124-1128.

Funke, G., von Graevenitz, A., Clarridge, J. E., III \& Bernard, K. A. (1997). Clinical microbiology of coryneform bacteria. Clin Microbiol Rev 10, 125-159.

Funke, G., Osorio, C. R., Frei, R., Riegel, P. \& Collins, M. D. (1998). Corynebacterium confusum sp. nov., isolated from human clinical specimens. Int J Syst Bacteriol 48, 1291-1296.

Goyache, J., Vela, A. I., Collins, M. D. \& 7 other authors (2003). Corynebacterium spheniscorum sp. nov., isolated from the cloacae of wild penguins. Int J Syst Evol Microbiol 53, 43-46.

Kämpfer, P. \& Kroppenstedt, R. M. (1996). Numerical analysis of fatty acid patterns of coryneform bacteria and related taxa. Can J Microbiol 42, 989-1005.

Klatte, S., Kroppenstedt, R. M. \& Rainey, F. A. (1994). Rhodococcus opacus sp. nov., an unusual nutritionally versatile Rhodococcusspecies. Syst Appl Microbiol 17, 355-360.

Knox, K. L. \& Holmes, A. H. (2002). Nosocomial endocarditis caused by Corynebacterium amycolatum and other nondiphtheriae corynebacteria. Emerg Infect Dis 8, 97-99. 
Malik, A. S. \& Johari, M. R. (1995). Pneumonia, pericarditis, and endocarditis in a child with Corynebacterium xerosis septicemia. Clin Infect Dis 20, 191-192.

Martínez-Martínez, L., Suárez, A. I., Winstanley, J., Ortega, M. C. \& Bernard, K. (1995). Phenotypic characteristics of 31 strains of Corynebacterium striatum isolated from clinical samples. J Clin Microbiol 33, 2458-2461.

Ojeda-Vargas, M., González-Fernández, M. A., Romero, D., Cedrés, A. \& Monzón-Moreno, C. (2000). Pericarditis caused by Corynebacterium urealyticum. Clin Microbiol Infect 6, 560-561.

Renaud, F. N. R., Aubel, D., Riegel, P., Meugnier, H. \& Bollet, C. (2001). Corynebacterium freneyi sp. nov., $\alpha$-glucosidase-positive strains related to Corynebacterium xerosis. Int J Syst Evol Microbiol 51, 1723-1728.

Schleifer, K. H. \& Kandler, O. (1972). Peptidoglycan types of bacterial cell walls and their taxonomic implications. Bacteriol Rev 36, 407-477.

Shukla, K. S., Vevea, D. N., Frank, D. N., Pace, N. R. \& Reed, K. D. (2001). Isolation and characterization of a black-pigmented
Corynebacterium sp. from a woman with spontaneous abortion. J Clin Microbiol 39, 1109-1113.

Sjödén, B., Funke, G., Izquierdo, A., Akervall, E. \& Collins, M. D. (1998). Description of some coryneform bacteria isolated from human clinical specimens as Corynebacterium falsenii sp. nov. Int $J$ Syst Bacteriol 48, 69-74.

Stackebrandt, E. \& Goebel, B. M. (1994). Taxonomic note: a place for DNA-DNA reassociation and $16 \mathrm{~S}$ rRNA sequence analysis in the present species definition in bacteriology. Int J Syst Bacteriol 44, 846-849.

Takeuchi, M., Sakane, T., Nihira, T., Yamada, Y. \& Imai, K. (1999). Corynebacterium terpenotabidum sp. nov., a bacterium capable of degrading squalene. Int J Syst Bacteriol 49, 223-229.

Tanner, M. A., Shoskes, D., Shahed, A. \& Pace, N. R. (1999). Prevalence of corynebacterial $16 \mathrm{~S}$ rRNA sequences in patients with bacterial and "nonbacterial" prostatitis. J Clin Microbiol 37, 1863-1870.

Vela, A. I., Fernández, E., Lawson, P. A., Latre, M. V., Falsen, E., Dominguez, L., Collins, M. D. \& Fernández-Garayzábal, J. F. (2002). Streptococcus entericus sp. nov., isolated from cattle intestine. Int J Syst Evol Microbiol 52, 665-669. 